\title{
Effectiveness of the Heads of Schools in Managing Financial Resources in Public Secondary Schools in Moshi Municipality
}

\author{
Samwel Edmund * Rev. Dr.Eugene Lyamtane** \\ Mwenge Catholic University \\ Faculty Of Education \\ P.O.Box 1226 \\ (Moshi- Tanzania
}

\begin{abstract}
This study examined the effectiveness of the Heads of Secondary Schools in Managing Financial Resources in Public Secondary Schools in Moshi Municipality. It was guided by thefollowing research questions: To what extent do Heads of Schools implement the procedures in managing Schools finances? What are the procedures of disbursing, ensuring safe custody, procurements and payments of the School finances? What are the challenges facing head of schools in managing financial resources in secondary schools in Moshi municipality? What should be done to improve the management of financial resources in secondary school in Moshi Municipality? This study was quantitative research which employed cross sectional design. Stratified and simple random sampling procedures were used to obtain the participants. The instruments which were used in data collection were questionnaires, interview schedule and observation schedule. The researcher used quantitative methods to analyze data.The Statistical Package for Social Sciences (SPSS version 16) was used to generate data that was used to test the hypotheses. One way ANOVA was used to test all hypotheses. Findings show that Heads of schools do not adhere to the financial guidelines given out by the Government. Also procurements procedures at School are not adhered as the Government guidelines direct. The findings as well show that, financial documents management in Public Secondary Schools in Moshi Municipality does not follow the Government directives.Basing on the findings the following were concluded; Heads of Schools are ineffective and perform poorly in managing the school financial resources. They do not adhere to the procurement procedures given by the Government and perform at satisfactory level ondisbursing and payments procedures of the School funds.
\end{abstract}

\section{Key words School finances, procurements and financial documents}

\section{Introduction}

Management of Secondary School finances in Tanzania has been a challenging activity to most of the Heads of Schools in last ten years. This is especially when the Government of Tanzania embarked on massive programs; the Primary Education Development Program (PEDP) and Secondary Education Development Program (SEDP) which started in 2002 following the elimination of school fees. According to United Republicof Tanzania (2006), the programs were efforts to translate the 1995 Tanzania's Educational and Training Policy (TETP) and the Education Sector Development Program (ESDP) into feasible strategies. The proper implementation of SEDP necessitated the introduction of several guidelines, some of them being financial management accounting guidelines and procurement guidelines.

The purpose of these guidelines is to enable those who will be involved in the day to day activities of the SEDP perform their duties in an orderly manner, transparently, effectively and efficiently while at the same time providing the necessary information for effective decision making.

It implies therefore, management of financial matters related to education and procurement of educational materials is now carried at School level. The Secondary School administration has the authority to oversee and administer all the financial matters. Thus, the budget of $30,000=/$ T.sh annually has been set and 
allocated for each pupil to make available other resources for improving quality of Secondary Education (BEDC, 2004)

\section{Statement of the Problem}

Haki Elimu (2003) points it out that there have been series of allegations levied against school administrators that they don't follow up the financial guidelines given to them for SEDP implementation in such a way that school administrators are accused of mismanaging and embezzling money put in their custody. So far there are no substantial evidences that have been strongly put forward to back up on all these allegations.

Several studies have been conducted; however, no study on effectiveness of Heads of Public Secondary School on managing school finances in relation with the financial guidelines especially in Tanzania has been done. Therefore this study investigated the effectiveness of heads of school in managing financial resources in Public Secondary School in Moshi Municipality.

\section{Research Questions}

The study was guided by the following research questions:

1. To what extent do Heads of Schools implement the procedures in managing School finances?

2. What are the proceduresof disbursing, ensuring safecustody, procurements and payments of the School finances?

3. How are School financial documents managed in public Secondary Schools in Moshi municipality?

4. What are the challenges facing Head of Schools in managing financial resources in Secondary Schools in Moshi municipality?

5. What should be done to improve the management of financial resources in Secondary School in Moshi municipality?

\section{Hypotheses}

1. There is no relationship between the Heads of School gender and the level of financial resources management of School.

2. There is no relationship between the age of the Heads of Schools and the level of financial resources management.

3. There is no relationship between the Heads of Schools experience and the level of School financial resources management.

\section{Significance of the study}

This study is important for the following reasons:

First, it will help head of schools to know their roles as school financial resources controller/managers in his/her institution. It is therefore an attempt to contribute to other studies done on financial resources management in public secondary schools. Consequently, the study will provide a clear insight into parents/guardians on the way financial resources are being administered within the school.

Second, the study will serve as a foundation in providing relevant information on the manner head of school manage and administer financial resources in public secondary schools for the purpose of attaining/accomplishing the educational goals. Therefore, it will provide suggestions to assists in giving a direction in the process of monitoring, evaluation and support for the appropriate training on management of finances in public secondary schools. As well it will help educational officers to make follow up on the proper use of the resources allocated to the school and act upon any misuse of funds.

Lastly, the central government and local government will play their roles effectively on allocating enough and on time financial resources to the school and making evaluation through auditing and any other mechanism suggested.

\section{Scope and Delimitation of the study}

The study was carried out in one Moshi Municipality which is one among the six districts of Kilimanjaro region. The selection of this district considered the given time to accomplish the task.

\section{Literature Review}

Various studies have been done on the management of financial resources by Head Teachers, Head of School and Principals. Among of studies are as follows: 
Njeru (2004) did a study on financial management practices of the head teachers in public secondary schools in central division, Embu district, in Kenya. The purpose of the study was to identify how the management of school finance is practiced in the targeted schools in the district.

Also, to determine any weaknesses of management associated with financial practices in the school. The study employed descriptive research (ex.post facto) incorporating a survey design.

The findings of the study indicated that majority of head teachers lack sufficient financial management skills.

Nyandoro (2003) examined the effectiveness of School Development Committees in financial management in Chimanimani West Circuit primary schools (Manicaland Province, Zimbabwe).Descriptive survey method was employed. The study revealed that School Development committees were not effective in managing funds for their schools due to lack of skills in various aspects of financial management such as preparation and use of budget for decision making, keeping inventory of school assets and raising funds. The researchers recommended the provision of capacity building program to the School Development Committees and parents in rural schools in Chimanimani West Circuit by the government, inclusion of a course on decentralization of education in teacher education curriculum and thorough supervision of School Development Committees to ensure school funds are managed properly in rural schools.

Ajileye (2001) conducted a study to examine the financial resources management capacity of Public Secondary school principals in Ondo State, Nigeria. It was also to investigate the ability of school administrators in utilizing available funds for the achievement of the goals and objectives of schools.

The study revealed that School administrators are able to use the funds generated fromother sources to achieve the following: improve the school farm, develop and buy sport equipment. The study also shown the school administrators are counted worthy to some extent in their capacity for preparing and executing the school budget for the running of school.

Mwijuma (2012) conducted a study in exploring perceptions of parents on head teachers' financial management skills in Public Primary schools in Tanzania. The purpose of this study was to examine the perceptions of parents on head teachers' financial management skills. The study adopted qualitative method, with a case study as a strategy to collect data.The findings revealed that head teachers and stakeholders in primary schools were lacking sufficient skills and capability to manage school consistent with the number of enrolled pupils were inadequate and not disbursed to the fullest, which to some extent hampered acquisition of other education materials.

Samples of empirical studies above varies in terms of School financial resources aspects where by other studies look on how management of financial resources is practiced, other study examined effectiveness of School committees in financial management, the other concentrated on the other aspect of principal capacity on managing school finances and the other study examined perceptions of the parents on head teachers finances management skills. The researchers used different approaches like quantitative approach, different techniques of data collection like case study, questions were employed and the findings were analyzed using different statistics measures whereby they revealed most head teachers,principals, parents and school committees or Board of governors lack financials management skills, transparency and accountability to the School funds

The literatures surveyed show that little has been done in terms of the findings, methodology and area of the study on the effectiveness of Heads of Secondary School in managing School financial resources in Tanzania. Therefore,it is from this scenario that the study necessity aroused so as to bridge the knowledge gap that existed in order to examine the effectiveness of the Heads of Schools in managing School financial resources.

\section{Research Design}

Cross sectional survey design was used. It was preferred because it allows large amount of data to be collected for ashort period of time and from a variety of people. Moreover, it allows the researcher to examine the characteristics of a sample such as the attitude, preference and interests. Cross sectional survey as well provides current practices, conditions or needs and describes performance of specific programs, products or organizations.

The study was conducted in 10 Secondary Schools among 14 Secondary Schools in Moshi Municipality where 10 heads of schools, 10 bursars, 100 teachers and 60 students were involved. 


\section{Data collection Instruments}

The instruments which were used to collect data were questionnaires, interview schedules and document analysis schedule.

Questionnaires were used to collect data from Heads of Schools, Teachers, and Students.

Interview Schedule was used to collect data from School Bursars on their perceptions, opinions, views feelings and motives towards various issues such as roles of head of school in School finances and on how effective the management of financial resources is in their Schools.

Document Analysis Schedule was used to collect data from School Bursars' office. The focus here was on different procedures of doing transactions in the School. Analysis of the annual School budget and examination of different financial guidelines, policies helped to determine effectiveness of the Head of School financial resources management.

\section{Findings}

The study was guided by five research questions and three hypotheses.

1. The extent to which Heads of Schools implement the procedures in managing School finances.The findings for this question were collected from teachers, students, head teachers and school bursars. The responses from the teachers and students are summarized in Table 1

Table 1 Responses of the teachers and students on procedures of managing school finances)

\begin{tabular}{|c|c|c|c|c|c|}
\hline Variables & $\begin{array}{l}\text { Very true } \\
\mathrm{f} \%\end{array}$ & $\begin{array}{l}\text { True } \\
\text { f } \%\end{array}$ & $\begin{array}{l}\text { No opinion } \\
\text { f } \%\end{array}$ & $\begin{array}{l}\text { Untrue } \\
\mathrm{f} \%\end{array}$ & $\begin{array}{l}\text { Very far from } \\
\text { the truth } \\
\text { f } \%\end{array}$ \\
\hline $\begin{array}{l}\text { Teachers response }(\mathbf{n}=\mathbf{1 0 0}) \\
\text { Collaboration with the school } \\
\text { management team }(\mathrm{SMT}) \text { prepares and } \\
\text { updates School development plans. }\end{array}$ & $27(27)$ & $51(51)$ & $4(4)$ & $4(4)$ & $9(14)$ \\
\hline $\begin{array}{l}\text { Compliance to the procurement } \\
\text { procedures as put forward by financial } \\
\text { management and accounting guidelines }\end{array}$ & $10(10)$ & $20(20)$ & $1(1)$ & 39 (19) & $30(30)$ \\
\hline $\begin{array}{l}\text { Head of School opens and operating } \\
\text { school bank accounts properly }\end{array}$ & $15(15)$ & $35(35)$ & $7(7)$ & $15(15)$ & $28(28)$ \\
\hline $\begin{array}{l}\text { Ensures that activities approved by } \\
\text { school board are implemented as } \\
\text { planned }\end{array}$ & $10(10)$ & $11(11)$ & $5(5)$ & $43(43)$ & $31(31)$ \\
\hline $\begin{array}{l}\text { Students Response }(\mathbf{n}=\mathbf{6 0}) \\
\text { Head of School informs students about } \\
\text { School plans in School Baraza }\end{array}$ & $3(5.0)$ & $22(36.7)$ & $4(6.7)$ & $35(50.0)$ & $1(1.7)$ \\
\hline $\begin{array}{l}\text { I read School plan and annual School } \\
\text { budget in a School notice board }\end{array}$ & $8(13.3)$ & $9(15.0)$ & $7(11.7)$ & $20(33.3)$ & $16(26.7)$ \\
\hline $\begin{array}{l}\text { School fees are normally paid through } \\
\text { School bank accounts }\end{array}$ & $33(55)$ & $23(38.3)$ & $0(0.0)$ & $0(0.0)$ & $4(6.7)$ \\
\hline $\begin{array}{l}\text { Official School receipts are given to } \\
\text { those who paid School fees }\end{array}$ & $31(51.7)$ & $15(25.0)$ & 7 (11.7) & $4(4.7)$ & $3(5.0)$ \\
\hline Lunch is taken at School & $37(61.7)$ & $20(33.9)$ & & $1(1.1)$ & $2(3.3)$ \\
\hline
\end{tabular}

As Table 1 indicates, majority of teachers who took part in the study (69\%) said that heads of Schools do not ensure compliance with the procurement procedures as put forward by financial management and accounting guidelines, while minority (10\%) said that heads of schools adhere to the procurement procedures. These findings concur with the document analysis done by the researcher where-by the document on guidelines manual for procurement procedures for SEDP II was missed in schools. 
Furthermore, (74\%) of the teachers as well said that heads of schools do not implement all activities as planned by the school board. The interview done to a school bursar as well support the findings that heads of schools do not implement the plans approved by the school board. This scenario could be due to a number of reasons like scarcity of funds from the Government, lack of cooperation from parents and poor knowledge on plans implementation

Findings in Table 1 show that $60 \%$ of students who were involved in the study said school plans and annual school budget are not posted on the school notice Board for them to read as Government ordered while 28. $3 \%$ said that they are posted. This result imply that, majority $60 \%$ of the students were not informed about the school plans and annual school budget through notice board as directed by the financial accounting guidelines.

When the heads of schools were asked on how they procedurally manage the school finances they responded as indicated in Table 2

Table 2 Responses of the head of School on procedures of managing school finances)

\begin{tabular}{|c|c|c|c|c|c|}
\hline $\begin{array}{l}\text { Variables } \\
\text { Head of School Response }(n=10)\end{array}$ & $\begin{array}{l}\text { Never } \\
\text { f }(\%)\end{array}$ & $\begin{array}{l}\text { Rarely } \\
\text { f (\%) }\end{array}$ & $\begin{array}{l}\text { Responses } \\
\text { Sometimes } \\
\mathrm{f}(\%)\end{array}$ & $\begin{array}{l}\text { Often } \\
f(\%)\end{array}$ & $\begin{array}{c}\text { Always } \\
\text { f }(\%)\end{array}$ \\
\hline $\begin{array}{l}\text { Collaboration with the school management } \\
\text { team (SMT) prepares and updates School } \\
\text { development plans. }\end{array}$ & $0(0)$ & $1(10)$ & $3(30)$ & $4(40)$ & $2(20)$ \\
\hline $\begin{array}{l}\text { Compliance to the procurement procedures } \\
\text { as put forward by financial management and } \\
\text { accounting guidelines }\end{array}$ & $0(0)$ & $0(0)$ & $4(40)$ & $4(40)$ & $2(20)$ \\
\hline $\begin{array}{l}\text { Construction money given by the } \\
\text { government follows the procedures to do the } \\
\text { same }\end{array}$ & $0(0)$ & $6(60)$ & $0(0)$ & $4(40)$ & $0(0)$ \\
\hline $\begin{array}{l}\text { Head of School opens and operating school } \\
\text { bank accounts properly }\end{array}$ & $0(0)$ & $0(0)$ & $0(0)$ & $0(0)$ & $10(100)$ \\
\hline $\begin{array}{l}\text { School activities approved by School Board } \\
\text { are implemented as planned }\end{array}$ & $0(0)$ & $2(20)$ & $1(10)$ & $4(40)$ & $3(30)$ \\
\hline $\begin{array}{l}\text { Implementation of the financial guidelines as } \\
\text { instructed by the Ministry of education }\end{array}$ & $3(30)$ & $3(30)$ & $2(20)$ & $2(20)$ & $0(0)$ \\
\hline $\begin{array}{l}\text { Submission to the MOEVT all documents } \\
\text { related to the plan implementation for } \\
\text { accounting purposes }\end{array}$ & $0(0)$ & $6(60)$ & $3(30)$ & $1(10)$ & $0(0)$ \\
\hline $\begin{array}{l}\text { Preparation of annual school budget and } \\
\text { present it prior to a given financial year }\end{array}$ & $0(0)$ & $7(70)$ & $1(10)$ & $0(0)$ & $0(0)$ \\
\hline $\begin{array}{l}\text { Preparation of all financial reports in } \\
\text { quarterly and basis and submit to the } \\
\text { MOEVT }\end{array}$ & $7(70)$ & $3(30)$ & $0(0)$ & $0(0)$ & $0(0)$ \\
\hline
\end{tabular}

As shown in Table 2 indicate that, $60 \%$ of the Heads of Schools who participated in the study admitted that they were not implementing the financial guidelines as instructed by the Ministry of education while $30 \%$ said they were sometimes following the instructions and $10 \%$ said they were always following the instructions. Therefore this implies that there is poor effectiveness of the financial resources management in schools. The findings is supported by Sigilai and Bett (2013) who said that most of the Head Teachers were found to be ineffective in the management of School finance because they were already overworked with administrative duties and class work. 
The findings from Table 2 indicate that majority of the Heads of Schools who were involved in the Study $(60 \%)$ said that Government procedures in all School procurement process are always adhered to while the minority (40\%) maintained that they are sometimes adhered to. The findings are contrary with the findings from the interview done by the researcher to the School bursars where by majority $(70 \%)$ said Heads of Schools do not adhere to the procurement procedures like tendering procedures, and offering of tenders. The findings are in agreement with the findings in Table1 where teachers maintained that Heads of Schools do not adhere to the procurements procedures as the guidelines direct. Generally, this imply that Heads of Schools do not adhere to the procurement procedures as directed by the financial management guidelines as the result it may cause improper management of the School fund or misallocation of the funds in different School activities. But if the procurements procedures are followed as directed to the guidelines, misallocation or misuse of the funds in Schools procurements will be curbed.

Data in Table 2 reveal that, $60 \%$ of the Heads of Schools who participated in the study said that they always collaborate with the School management team in preparation and implementation of the School plans while $30 \%$ said they do it sometimes. The findings generally imply that the Heads of Schools in Moshi Municipality involve the School team in different School activities especially in planning and implementation of those plans. The Heads of Schools responses concur with the teachers responses who supported that Heads of Schools do collaborate with BEDC (2010-2015), the financial guidelines by Government which call for each school to have a management team comprising of the Head of school, Deputy Head, School Accountant, Academic Master and Discipline Master.

The results in Table 2 show that $70 \%$ of the Heads of Schools who participate in the study admitted that there was no preparation of annual School budget and presentation prior to a given financial year while $30 \%$ said it was sometimes done. The findings in this case are contrary to the requirement of the financial guidelines for Secondary Schools. Budget is an important tool in the day today running of any education institution as it serve as a tool for economic and financial management as well as accountability and mechanism for allocating resources among different needs and priorities as well as bringing economic stability and growth (MFEC,2007). The result therefore implies that Heads of Schools may use the available resources to unplanned activities because of late preparation and presentation of the School budget.

The Bursars responses on the same issue is summarized in Table 3

Table 3 Responses of the School bursar on procedures of managing school finances)

\begin{tabular}{|c|c|c|c|c|c|}
\hline $\begin{array}{l}\text { Variables } \\
\text { School Bursars Response }(n=10)\end{array}$ & $\begin{array}{l}\text { Excellent } \\
\mathrm{f}(\%)\end{array}$ & $\begin{array}{l}\text { Very good } \\
\text { f }(\%)\end{array}$ & $\begin{array}{r}\text { Good } \\
\mathrm{f}(\%) \\
\end{array}$ & $\begin{array}{l}\text { Poor } \\
\mathrm{f}(\%)\end{array}$ & $\begin{array}{l}\text { Very poor } \\
\mathrm{f}(\%)\end{array}$ \\
\hline $\begin{array}{l}\text { Rate the School budget preparation } \\
\text { and implementation }\end{array}$ & $0(0)$ & $3(30)$ & $1(10)$ & $4(40)$ & $2(20)$ \\
\hline Rate the School payments procedures & $0(0)$ & $8(8)$ & $0(0)$ & $2(20)$ & $0(0)$ \\
\hline $\begin{array}{l}\text { Rate the implementation of the } \\
\text { financial management and accounting } \\
\text { guideline }\end{array}$ & $1(10)$ & $2(20)$ & $0(0)$ & $7(70)$ & $0(0)$ \\
\hline Rate the School auditing procedures & $0(0)$ & $3(30)$ & $2(20)$ & $5(50)$ & $0(0)$ \\
\hline Rate the School money authorization & $0(0)$ & $3(30)$ & $2(20)$ & $2(20)$ & $3(30)$ \\
\hline
\end{tabular}

Data from Table 3 show that majority of the School bursars $60 \%$ pointed out that the preparation and implementation of the School budget was poor while 30\% said it was very good and $10 \%$ said it was good. From the results it implies that there is poor preparation of the School budget as a result there could be poor implementation of the budget hence poor management of the School funds. Ajileye (2001) said School administrators are counted worthy to some extent in their capacity for preparing and executing the School budget for the running School.

Findings in Table 3 indicate that most of the Heads of Schools (70\%) implement poorly the procedures of managing the school finances given by the Government through the financial management and accounting 
guidelines. So the extent Heads of Schools implement the procedures in managing School finances is not encouraging and does not adhere to the financial guidelines given by the Government. Sigilai and Bett (2013), emphasize that, Head teachers are overall in charge of all matters pertaining to budgeting and accounting of School funds, record keeping and maintenance of facilities and supplies in the School. Head teachers have to make budgeting, correspondence, accounting verification, checking up to date entries in the registers and documents of the School (Mohanty, 2002)

\section{Safe custody, disbursing, payments and procurement procedures}

Research question aimed at gathering information on the way the heads of secondary schools safe guard the school finances in the course of various transactions. The responses from various respondents are summarized in Table 4.

Table 4 Responses of the teachers, heads of schools and school bursars on heads of schools procedures of ensuring disbursing, safe custody, procurements and payments of the school finances

\begin{tabular}{|c|c|c|c|c|c|}
\hline Variables & $\begin{array}{l}\text { Very } \\
\text { true } \\
\mathrm{f}(\%)\end{array}$ & $\begin{array}{l}\text { True } \\
\mathrm{f}(\%)\end{array}$ & $\begin{array}{l}\text { No } \\
\text { Opinion } \\
\mathrm{f}(\%)\end{array}$ & $\begin{array}{l}\text { Untrue } \\
\mathrm{f}(\%)\end{array}$ & $\begin{array}{l}\text { Very far } \\
\text { from the } \\
\text { truth } \\
\mathrm{f}(\%)\end{array}$ \\
\hline $\begin{array}{l}\text { Teachers response } \mathbf{n}=\mathbf{1 0 0} \\
\text { Compliance to the procurement procedure } \\
\text { Grants from the government } \\
\text { Scholarship grant } \\
\text { Capitation grant } \\
\text { Development grant } \\
\text { Payments through bank accounts } \\
\text { Safe custody of the School fund } \\
\text { School payment procedures }\end{array}$ & $\begin{array}{l}17(17) \\
19(19) \\
12(12) \\
24(24) \\
9(9) \\
41(41) \\
42(42) \\
32(32)\end{array}$ & $\begin{array}{l}37(37) \\
41(41) \\
24(24) \\
38(38) \\
21(21) \\
48(48) \\
45(45) \\
41(41)\end{array}$ & $\begin{array}{l}2(2) \\
12(12) \\
9(9) \\
1(1) \\
12(12) \\
7(7) \\
12(12) \\
6(6) \\
\end{array}$ & $\begin{array}{l}21(21) \\
27(27) \\
32(32) \\
16(16) \\
32(32) \\
4(4) \\
1(1) \\
19(19)\end{array}$ & $\begin{array}{l}23(23) \\
- \\
23(23) \\
21(21) \\
26(26) \\
\quad- \\
- \\
2(2) \\
\end{array}$ \\
\hline $\begin{array}{l}\text { Head of School responses } \mathbf{n}=\mathbf{1 0} \\
\text { Safe custody of the School fund } \\
\text { Opens and operating school bank accounts } \\
\text { School payments in cash system } \\
\text { Grant from the Government } \\
\text { Students scholarship from the government } \\
\text { Capitation grant for books, stationery etc } \\
\text { Development grant do its purpose } \\
\text { School receipts are offered after payments } \\
\text { Head of school authorize all payments } \\
\text { All payments are done through school } \\
\text { bank accounts }\end{array}$ & $\begin{array}{l}10(100) \\
- \\
7(70) \\
8(80) \\
- \\
- \\
3(30) \\
7(70) \\
10(100) \\
6(60)\end{array}$ & $\begin{array}{l}- \\
- \\
2(20) \\
- \\
2(20) \\
7(70) \\
2(20) \\
- \\
- \\
3(30)\end{array}$ & $\begin{array}{l}- \\
- \\
- \\
- \\
2(20) \\
2(20) \\
2(20) \\
3(30) \\
- \\
-\end{array}$ & $\begin{array}{l}- \\
- \\
1(10) \\
2(20) \\
2(20) \\
1(10) \\
3(30) \\
- \\
- \\
1(10)\end{array}$ & $\begin{array}{l}- \\
10(100) \\
- \\
- \\
4(40) \\
- \\
2(20) \\
- \\
- \\
-\end{array}$ \\
\hline $\begin{array}{l}\text { School bursars responses } \mathbf{n}=\mathbf{1 0} \\
\text { Custody of the school fund } \\
\text { School procurement procedures } \\
\text { School financial authorization procedures }\end{array}$ & $\begin{array}{l}3(30) \\
- \\
1(10)\end{array}$ & $\begin{array}{l}4(40) \\
3(30) \\
3(30)\end{array}$ & $\begin{array}{l}1(10) \\
- \\
-\end{array}$ & $\begin{array}{l}- \\
5(50) \\
1(10)\end{array}$ & $\begin{array}{l}3(30) \\
2(20) \\
-\end{array}$ \\
\hline
\end{tabular}

Table 4 shows that $64 \%$ of the Teachers and $70 \%$ of the School bursars who participated in the study said that Heads of Schools do not ensure compliance to the procurement procedures. The findings concur with the document analysis done by the researcher in the bursars and Heads of Schools office to find out the availability of procurement document like the procurement manual guidelines that was suggested by the Ministry of Education to be used to all Secondary Schools in Tanzania. Absence of and lack of compliance to the procurements procedures in Schools may cause fraud in procurements process hence poor management of the Schools funds. 
Findings in Table 4 indicate that $61 \%$ of the teachers and $80 \%$ of the Heads of Schools who are involved in the study said that Government normally sends grants to Schools. These findings are in agreement with the interview done to the School bursars who almost all of them agree that the School receives grants from the Government every year but the grant is not sent to Schools on time as well is not sent per requirements of the School.

As shown in Table 4 show that $87 \%$ of the teachers, $70 \%$ of the School Bursars and all Heads of Schools who participated in the study said Schools have Bank accounts for the safe custody and proper usage and management of the School funds. Therefore, availability of School Bank accounts ensures the proper School financial management for all the money is deposited into the Bank account before it is used and hence laying a good foundation for proper usage and effectiveness in managing the School funds.

Furthermore, the findings in Table 4 indicate that $73 \%$ and $90 \%$ of the Teachers, Heads of School and School bursars respectively, said that Heads of Schools adhere to the School money authorization procedures as stipulated in the financial management accounting guidelines for Secondary Schools.

Table 4 shows that $70 \%$ of the Heads of Schools who participated in the study said School always offer School receipts to any payments that is done to School while $30 \%$ they had no any opinion. The findings therefore are in agreement with the document analysis done by the researcher to all Schools in a study whereby $(80 \%)$ of the Schools have Government receipts books which are used by the Schools in the process of any payment at School

\section{School financial documents management.}

Financial management demands proper preparation of the books of accounts. Responses from different respondents are given in Table 5.

Table 5 Responses of the Teachers, Heads of Schools and School bursars on Head of Schools financial documents management

\begin{tabular}{|c|c|c|c|c|c|}
\hline Variables & $\begin{array}{l}\text { Very } \\
\text { true } \\
\mathrm{f}(\%)\end{array}$ & $\begin{array}{l}\text { True } \\
\mathrm{f}(\%)\end{array}$ & $\begin{array}{l}\text { No } \\
\text { Opinion } \\
\mathrm{f}(\%)\end{array}$ & $\begin{array}{l}\text { Untrue } \\
\mathrm{f}(\%)\end{array}$ & $\begin{array}{l}\text { Very far } \\
\text { from the } \\
\text { truth } \\
\mathrm{f}(\%)\end{array}$ \\
\hline $\begin{array}{l}\text { Teachers response } \mathbf{n}=\mathbf{1 0 0} \\
\text { Preparation of the school financial reports/ } \\
\text { documents } \\
\text { Availability and usage of the financial } \\
\text { documents } \\
\text { School board approves School financial } \\
\text { documents }\end{array}$ & $\begin{array}{l}20(20) \\
43(43) \\
15(15)\end{array}$ & $\begin{array}{l}55(55) \\
38(38) \\
27(27)\end{array}$ & $\begin{array}{l}10(10) \\
17(17) \\
-\end{array}$ & $\begin{array}{l}9(9) \\
- \\
20(20)\end{array}$ & $\begin{array}{l}6(6) \\
2(2) \\
38(38)\end{array}$ \\
\hline $\begin{array}{l}\text { Head of School responses } \mathbf{n}=\mathbf{1 0} \\
\text { Financial reports preparation follows the } \\
\text { government guidelines } \\
\text { Submission to the MOEVT all financial } \\
\text { reports } \\
\text { Quarterly financial reports preparation } \\
\text { School Board approves financial } \\
\text { documents } \\
\text { Availability and usage of the school } \\
\text { financial payments procedures }\end{array}$ & $\begin{array}{l}2(20) \\
- \\
- \\
- \\
4(40)\end{array}$ & $\begin{array}{l}3(30) \\
3(30) \\
- \\
4(40) \\
3(30)\end{array}$ & $\begin{array}{c}- \\
1(10) \\
2(20) \\
- \\
-\end{array}$ & $\begin{array}{c}5(50) \\
6(60) \\
3(30) \\
- \\
-\end{array}$ & $\begin{array}{l}- \\
- \\
5(50) \\
6(60) \\
3(30)\end{array}$ \\
\hline $\begin{array}{l}\text { School bursars responses } \mathbf{n}=\mathbf{1 0} \\
\text { Scholl financial reports preparation } \\
\text { procedures }\end{array}$ & $4(40)$ & $2(20)$ & - & - & $4(40)$ \\
\hline
\end{tabular}




\begin{tabular}{|l|l|l|l|l|l|}
\hline $\begin{array}{l}\text { School plans and budget preparation and } \\
\text { implementation }\end{array}$ & - & $4(40)$ & $2(20)$ & - & $4(40)$ \\
\hline
\end{tabular}

The findings in Table 5 show that $75 \%$ of the teachers, $50 \%$ of the Heads of Schools and $60 \%$ of the School Bursars reports as instructed by the Ministry of Education. The findings are in agreement with the findings from the document analysis done by the researcher whereby one among the documents found in almost all schools were different financial reports prepared by Schools and submitted to the Ministry of Education. This implies therefore that there are some financial documents in Schools for further reference as a result the financial records adhere to the Government requirements of preparing and keeping the School financial reports.

Furthermore, Data in Table 5 show that $58 \%$ of the teachers and $60 \%$ of the Heads of Schools who participated in the study responded that School board does not approve School financial documents like annual School budget, School plans and all financial reports. This implies therefore that Schools uses some of the financial documents like School plans and School budget without the approval of the School board as the directions from the Government guidelines states as results it may lead to the poor financial management of the School funds.

Data in Table 5 indicate that $60 \%$ of the School bursars who participated in the study said they do not prepare and implement the School plans and School budget as the financial guidelines from the Government require. When asked further to explain their answers $60 \%$ of the School bursars said they are not skillful in preparing School plans and School annual budget because they are not the professional accountant. They further explain that, the poor implementation of the School plans and School budget is due to the poor preparation, $90 \%$ of the bursar said its because Head of Schools lack financial management skills and almost all of them commented that, poor implementation of the School budget is due to scarcity of funds from the Government and parents. Mwijuma (2012) said that Head Teachers and stakeholders in Primary Schools were lacking sufficient skills and capability to manage School finance. He further commented that, funds which were supposed to be allocated to School consistent with the number of enrolled pupils were inadequate and not disbursed to the fullest, which to some extent hampered acquisition of other educational materials. Okumbe (1998) said a well-formulated School budget should consist of an education plan, expenditure plan and a revenue plan.

Challenges facing heads of schools in managing school financial resources

The heads of schools, teachers and school bursars identified challenges facing heads of schools in the course of managing the school funds. The challenges are:-

a) Delays of the funds from the government and parents which affects the implementation of school plans and programs.

b) Insufficient funds from the government. This makes it difficult for schools to finish various projects on time.

c) Poor knowledge of the heads of schools in managing school financial resources. This scenario could be due to lack of in-service training for heads of school

d) Lack of school bursar. Majority of schools do not have qualified accountants instead they use teachers. Lack of professional accountants makes it difficult for schools to prepare accurate data, comply to accounting standards and identifying operational errors.

e) Poor cooperation from the parents in paying school fees.

Suggestions to improve the management of the school financial resources

To address the aforementioned challenges the following suggestions are made:-

a) Government should allocate enough funds to schools for effective implementation of the schools programs.

b) Heads of schools should attend seminars or workshop on financial resources management. Such trainings will enabled them to always make informed financial decisions.

c) Government should employ professional school bursars in schools. Adherence to the accounting international standards requires a well trained accountant.

d) Funds allocated to schools should be sent on time to enable the school administrators implement the schools plans or budget as required. 
e) School fees from parents should be paid to schools on time. The cost shared by parents is meant to create conducive teaching and learning environment. If it is not paid on time it can frustrate the schools plan and eventually affect the quality of education given to our children.

\section{Hypotheses Testing}

The study sought to investigate the relationship between the variables under study. The relationship were determined by using one way ANOVA at 0.05 level of significant which is accepted in social sciences. Null hypothesis were stated, tested and the results were as follows.

\section{Null hypothesis 1}

There is no statistically significant relationship between Head of School gender and the level of School resources management

Table 6 ANOVA Summary Table

\begin{tabular}{|l|r|r|r|r|r|}
\hline & \multicolumn{1}{|c|}{$\begin{array}{c}\text { Sum of } \\
\text { Squares }\end{array}$} & \multicolumn{1}{c|}{ Df } & $\begin{array}{c}\text { Mean } \\
\text { Square }\end{array}$ & F & Sig. \\
\hline $\begin{array}{l}\text { Between } \\
\text { Groups }\end{array}$ & .900 & 1 & .900 & 4.800 & .060 \\
\hline Within Groups & 1.500 & 8 & .188 & & \\
\hline Total & 2.400 & 9 & & & \\
\hline
\end{tabular}

From the statistical test the finding indicate that, P-value $0.060 \geq 0.05$ then we do not reject the researchers claim (Null hypothesis) therefore there is no statistically relationship between Head of School gender and the School financial resources management in public Secondary Schools in Moshi urban district. Therefore Head of School Gender (male or female) cannot influence the effectiveness of the School financial resources management.

\section{Null hypothesis 2}

There is no statistically significant relationship between Head of School age and the level of School resources management Table 7 ANOVA Summary Table

\begin{tabular}{|l|r|r|r|r|r|}
\hline & \multicolumn{1}{|c|}{$\begin{array}{c}\text { Sum of } \\
\text { Squares }\end{array}$} & \multicolumn{1}{c|}{ Df } & $\begin{array}{c}\text { Mean } \\
\text { Square }\end{array}$ & F & Sig. \\
\hline $\begin{array}{l}\text { Between } \\
\text { Groups }\end{array}$ & .025 & 1 & .025 & .084 & .779 \\
\hline Within Groups & 2.375 & 8 & .297 & & \\
\hline Total & 2.400 & 9 & & & \\
\hline
\end{tabular}

From the statistical test the finding indicate that, $\mathrm{P}$-value $0.779 \geq 0.05$ then we do not reject the researchers claim (Null hypothesis) therefore there is no statistically relationship between Head of School age and the School financial resources management in public Secondary Schools in Moshi urban district. Therefore Head of School age cannot influence the effectiveness of the School financial resources management.

\section{Null hypothesis 3}

There is no statistically significant relationship between Head of School experience and the level of School resources management

Table 8 ANOVA Summary Table

\begin{tabular}{|c|c|c|c|c|c|}
\hline & $\begin{array}{c}\text { Sum of } \\
\text { Squares }\end{array}$ & Df & $\begin{array}{c}\text { Mean } \\
\text { Square }\end{array}$ & F & Sig. \\
\hline
\end{tabular}




\begin{tabular}{|l|r|r|r|r|r|}
\hline $\begin{array}{l}\text { Between } \\
\text { Groups }\end{array}$ & 1.900 & 3 & .633 & 7.600 & .018 \\
\hline Within Groups & .500 & 6 & .083 & & \\
\hline Total & 2.400 & 9 & & & \\
\hline
\end{tabular}

From the statistical test the finding indicate that, P-value $0.01<0.05$ then we reject the researchers claim (Null hypothesis), therefore there is statistically relationship between Head of School experience and the School financial resources management in public Secondary Schools in Moshi urban district. Therefore Head of School experience in working area can influence the effectiveness of the School financial resources management.

\section{Conclusions}

Basing on the findings the following can be concluded; heads of Schools are ineffective in managing the School financial resources so the Government should provide financial resources in-service training and workshops to the heads of schools so as to equip them with financial management techniques hence effective financial resources management.

Most of the heads of schools do follow the procedures given by the MOEVT on the safe custody of the funds by opening school bank accounts and use them effectively as directed by thefinancial Management guidelines, so they should be encouraged to do the same. On the other hand, heads of schools do not adhere to the procurement procedures given by the government and perform at satisfactory level on disbursing and payments procedures of the school funds. So the Government should take immediate measures to enhance Heads of Schools with skills on disbursing, payments andProcurements procedures as well they should employ professional School accountant so as to reduce and solve these problems.

Most of the Heads of Schools perform poorly in managing the School financial reports which is an indication that there is ineffective management of the School funds. So employment of the qualified School accountant is of great important to the Schools.

Heads of Schools are facing many challenges like insufficient funds from the Government, delays of the fund, absence of the qualified School accountant and insufficient skills in managing the School finances as the as the results suggestions like employing the qualified School accountant, provision of the workshops and seminars to the Head of School were given out so as to help the Head of School to manage the School finances effectively.

\section{Recommendations}

From the findings some issues like absence of the qualified school accountant and delays of the grants from the government to run the schools were raised. Therefore it can be recommended that the government should take immediate measures to employ the qualified school accountants to schools who would help heads of schools in managing the school finances effectively by preparing school budget, plans and all other documents that are needed at schools.

Furthermore, the government should introduce in-service training and workshop about financial resources management for head of public secondary schools to attend so as they can acquire some skills in managing the school finances effectively.

Lastly, the government should allocate enough funds to schools and send the money to schools on time by reducing the bureaucratic procedures on the availability of the funds to school. The school should get exactly the required fund that has been allocated and on time so as the school could implement their plans.

\section{References}

[1] Ajileye (2001), Financial Resources Management capacity of Public Secondary School Administrators in Ondo state, unpublished (MA), University of Port Harcout, Nigeria.

[2] Ary.D.Jacobs,C.L, \& Razavieh, A (2002) .Introductiion to Research in Edu ation. (6 ${ }^{\text {th }}$ Edn). USA:Wadswoth

[3] Cohen,L.Manion \& Morrison, K,(2000). Research Methods in Education. (5 ${ }^{\text {th }}$ ed.). London: Routledge 
[4] Fraenkel and Wallen (2000), How to design and Evaluate research in Education. (4 ${ }^{\text {th }}$ ed).San. Francisco State Unifersity,New York

[5] George.D \& Mallery,P.(2003).SPSS for Windows step by step: A simple Guide and Reference.11.0 update $\left(4^{\text {th }} \mathrm{Ed}\right)$. Boston: Allyn \& Bacon.

[6] Hakielimu (20030, The primary Education Development Plan (PEDP),SUMMARY, Hakielimu Working papers, Dar es salaam, HAKIELIMU.

[7] Hansraj I (2007), The financial management role of Principal in section 21 Schools in South Durban, unpublished (MA) Dissertstyion, Kwazulu-Natal,Uni versity of South Africa

[8] Komba,A.A. (2003). The Capitation and Investment Grants as a Strategy for Financing Primary Education in Tanzania . Unpublished MA (Education) Dissertastion. Uni versity of Dar es sallam

[9] Molocho,N.W. (1998) Kilimanjaro Region Socio-Economic Profile. The Planning Commission Dar es salaam Regional Commissioner's Office Kilimanjaro.

[10] Milanesi. J.Mhina. A.\& Contamin. B. (2010).The improvement of the sanitation services in Moshi (Tanzania).

[11] Mwaijuma J.S (2012), Exploring perceptions of Parents on Heads teacher's financial Management skills in Public Primary Schools in Tanzania, unpulished (MA),Dissertation studies, University of Dar es salaam.

[12] Njweru.J.W (2004).Financial management practices of the Heads Teachers in public secondary

[13] Schools in central division, Embu district, Kenya.

[14] Nyandoro (2003),Effectiveness of school development committees in financial management in

[15] Chimanimani west circuit Primary Schools in Zimbabwe, unpublished (MA) paper work, Africa University, Zimbabwe.

[16] Ogula,P.(2009). Principles and Practice of Teaching and Learning. A handbook for Teachers and educators. Port Victoria: New Kermit.

[17] Okumbe,A.J.(2007) .Education Management Theory and Practice. Nairobi: Nairobi University Press

[18] REPOAand Ministry of Finance-URT. (2004) "Tanzania Public expenditure Tracking study"

[19] Study of the Financial and Non-Financial PEDP Flows from Central Government to Schools in 200s and 2003. Government Printing Unit, Tanzania.

[20] Salkind. N.J.(2005). Exploring research $6^{\text {th }}$ edition. New Jersey: Pearson.

[21] Palela.E. (2012). The Management of Sanitation Services: The Case of Moshi Urban

[22] Environmental Regulation. Retrieved on $8^{\text {th }}$ October, 2013 from http://www.pseau org/epa/gdda/Regulation environnementale.pdf

[23] Samoff.J.(1987). Schoool expansion in Tanzania : Private Initiatives and Public Policy.

[24] Omparative Education Review, 31 (3) : pp.333-360.

[25] Teklemariam,A.A.(2009). Managing Education , A Handbook for Student-Teachers, Trainers and School Principals. Nairobi:CUEA Press

[26] United Republic of Tanzania (2003). "Joint Review of the PEDP", A Report by Ministry of Education and culture and President's Office-Regional Administration and Local Government . Dar es salaam

[27] United Republic of Tanzania (2006). Education and Training Sector Development Programme:

[28] Primary Education Dwevelopment Programme II. Basic Education Committee. Dae es salaam

[29] United Republic of Tanzania (2006). Regional and District Projections. Kilimanjaro Region.

[30] National Bureau of Statistics Ministry of Planning, Economy and Emplowerment. Volume XIII. Dar es salam World Bank.(2007) What do we Know About School Based Management ?World Bank, Washington DC 